\title{
CIVIL RIGHTS REMOVAL AFTER RACHEL AND PEACOCK: A LIMITED FEDERAL REMEDY
}

Congressional protection of civil rights has taken both substantive and procedural form. ${ }^{1}$ One major procedural guarantee, first enacted in the post Civil War period, ${ }^{2}$ permits removal of state criminal prosecutions $^{3}$ to the federal courts under certain circumstances. Early Supreme Court decisions restricted the applicability of this civil rights removal provision to the situation where a facially unconstitutional state statute is involved. ${ }^{4}$ In the early 1960's the lower federal courts began to reconsider and expand the scope of this removal provision, ${ }^{5}$ and in 1966 the Supreme Court, at the invitation of Congress, ${ }^{6}$ reexamined it for the first time in sixty years. ${ }^{7}$ The Court's decisions in Georgia $v$. Rachel ${ }^{8}$ and City of Greenwood v. Peacock deviated somewhat from the early line of cases but rejected major expansion of what is now section 1443 of title 28. The petitioners in Rachel and Peacock were black persons who had exercised their civil rights, and white persons aiding them in that pursuit, who claimed that the various state criminal charges against them had no basis in fact, that the arrests and prosecutions were racially motivated, and that as a result they could not receive fair trials in a state court. ${ }^{10}$ In holding removal to be proper in Rachel but requiring remand to the state court in Peacock, the Court added to the "exquisite obscurity" of the statute.

1 Compare 18 U.S.C. § 245 (1970), with 28 id. § 1443.

2 Act of April 9, 1866, ch. 31, § 3, 14 Stat. 27.

328 U.S.C. § 1443 (1970), the present civil rights removal statute, applies to both civil and criminal cases. This Comment deals only with criminal cases since they have been primarily responsible for the litigation concerning this statute. text.

4 E.g., Virginia v. Rives, 100 U.S. 313 (1880); see notes 30-35 infra \& accompanying

5 See Peacock v. City of Greenwood, 347 F.2d 679 (5th Cir. 1965), rev'd, 384 U.S. 808 (1966); Rachel v. Georgia, 342 F.2d 336 (5th Cir. 1965), aff'd, 384 U.S. 780 (1966). But see Baines v. City of Danville, 357 F.2d 756 (4th Cir.), aff'd mem., 384 U.S. 890 (1966).

6 In $\S 901$ of the Civil Rights Act of 1964, 28 U.S.C. $\S 1447$ (d) (1970), Congress provided that "an order remanding a case to the State court from which it was removed pursuant to section 1443 of this title shall be reviewable by appeal or otherwise." The legislative history indicates that Congress intended that the federal appellate courts should reconsider the scope of 28 U.S.C. \& 1443 (1970), the civil rights removal statute. See, e.g., 110 Cong. Rec. 2770, 2773 (1964) (remarks of Representative Kastenmeier); id. 6564 (remarks of Senator Kuchel); id. 6955-56 (remarks of Senator Dodd).

7 The most recent case in which the Supreme Court interpreted the civil rights removal provision had been Kentucky v. Powers, 201 U.S. 1 (1906).

8384 U.S. 780 (1966).

9384 U.S. 808 (1966).

10 See text accompanying notes $39-41,57-61$ infra.

11 Amsterdam, Criminal Prosecutions Affecting Federally Guaranteed Civil Rights: Federal Removal and Habeas Corpus Jurisdiction to Abort State Court Trial, $113 \mathrm{U}$. PA. L. Rev. 793, 843 (1965). 


\section{INTRODUCTION}

Removal of a criminal prosecution from state court pursuant to section 1443 should be, in theory, a relatively simple and certain procedure for gaining access to a federal forum. A removal petition filed in federal district court prior to the commencement of the criminal trial automatically terminates all state proceedings unless and until the case is remanded to the state court..$^{12}$ In ordering a remand in Peacock the Supreme Court suggested that the petitioners had several alternative means of protecting their rights: a federal injunction against the state prosecution, ${ }^{13}$ appeal to the Supreme Court from a state conviction, ${ }^{14}$ or federal habeas corpus after conviction..$^{15}$ However, to the criminal defendant in state court, removal possesses significant advantages over each of these alternatives. ${ }^{16}$ The filing of a claim for injunctive relief, unlike a removal petition, does not automatically halt the state prosecution. Furthermore, federal injunctions against state prosecutions are not easily obtainable since Younger v. Harris. ${ }^{17}$ Appeal to the Supreme Court is an uncertain remedy because of the delay, the small number of state convictions which the Court reviews, and the absence of factual determinations made in a federal forum. Habeas only sometimes provides a federal factfinder, ${ }^{18}$ and even when a hearing is provided the district court's finding is made against a background of a previous state determination of the facts. In addition, many cases will have become moot before the federal habeas stage due to the relative brevity of the prison sentences attached to most of the offenses for which individuals being harassed for the exercise of their civil rights are usually convicted.

The civil rights removal statute reads:

Any of the following civil actions or criminal prosecutions, commenced in a State court may be removed by the defendant to the district court of the United States for the district and division embracing the place wherein it is pending:

(1) Against any person who is denied or cannot enforce in the courts of such State a right under any law providing for the equal civil rights of citizens of the United States, or of all persons within the jurisdiction thereof;

(2) For any act under color of authority derived from

1228 U.S.C. \& 1446(e) (1970). See South Carolina v. Moore, 447 F.2d 1067, 1072-74 (4th Cir. 1971).

13384 U.S. at 829 (citing Dombrowski v. Pfister, 380 U.S. 479 (1965)).

14 Id. (citing Shuttlesworth v. Birmingham, 382 U.S. 87 (1965), and Thompson v. Louisville, 362 U.S. 199 (1960)).

15 Id. (citing Fay v. Noia, 372 U.S. 391 (1963), and Townsend v. Sain, 372 U.S. 293 (1963)).

16 See generally Amsterdam, supra note 11, at 794-99.

17401 U.S. 37 (1971).

18 See Townsend v. Sain, 372 U.S. 293 (1963). 
any law providing for equal rights, or for refusing to do any act on the ground it would be inconsistent with such law. ${ }^{19}$

In Peacock the Court concluded that subsection two protected only federal officers and those persons acting directly under their authority. ${ }^{20}$ That decision drastically limits the usefulness and significance of section 1443(2). Therefore this Comment will limit its discussion to the problems raised by section 1443(1), examining Rachel, Peacock, and the more recent opinions of the courts of appeals, in an attempt to determine what facts must be proven for removal to be sustained, and thus what facts must be alleged in order for the federal district court to hold an evidentiary hearing rather than remanding on the basis of the pleadings. Put briefiy and in the language of the statute, this Comment will examine what circumstances must be present prior to state trial to justify a determination that a defendant will be "denied or cannot enforce" in state court those federal rights protected by the removal statute. Before examining the cases it will be helpful to consider the legislative ancestry and early judicial history of civil rights removal in order to appreciate the task that faced the Supreme Court in 1966 and that continues to confront the lower federal courts.

\section{Legislative History and the Early Decisions}

The forerunner of the present civil rights removal statute was originally enacted in the third section of the Civil Rights Act of $1866{ }^{21}$ It provided for removal by defendants in state court "who are denied or cannot enforce" in the state courts any of the rights explicitly guaranteed them by the first section of that act. ${ }^{22}$ Thus there was no uncertainty as to which federal rights, when denied, provided a sufficient ground for removal. The ambiguous phrase, "any law providing for the

1028 U.S.C. \& 1443 (1970).

20384 U.S. at $814-24$.

21 Act of April 9, 1866, ch. 31, § 3, 14 Stat. 27.

The Thirty-ninth Congress passed the 1866 Civil Rights Act with the purpose of giving the freedmen the full measure of those rights secured by the Emancipation Proclamation and the thirteenth amendment. At least in part, the statute and especially the provision for removal in the third section was designed to counteract the Black Codes which were enacted in the Southern States during Reconstruction. See Amsterdam, supra note 11, at 814-18.

For a history of criminal removal prior to the Civil War, see Amsterdam, supra note 11, at 806-10. For a discussion of removal jurisdiction generally, see H. M. HART \& H. Wechster, The FEDERAL CoURTs AND THE FeDERAL SyStem 1019-51 (1953).

22 The first section of the act provided:

[United States] citizens, of every race and color without regard to any previous condition of slavery or involuntary servitude ... shall have the same right ... to make and enforce contracts, to sue, be parties, and give evidence, to inherit, purchase, lease, sell, hold, and convey real and personal property . . . as is enjoyed by white citizens, and shall be subject to like punishments, pains, and penalties, and to none other, any law, statute, ordinance, regulation, or custom, to the contrary notwithstanding.

Act of April 9, 1866, ch. 31, \& 1, 14 Stat. 27. Substantially the same substantive rights are now codified in 42 U.S.C. \$§ 1981-82 (1970). 
equal civil rights of citizens of the United States," defining the scope of civil rights removal jurisdiction, first appeared in the Revised Statutes of 1875 when Congress codified the substantive and removal provisions of the 1866 Act in separate sections. ${ }^{23}$ This codification resulted in uncertainty concerning which federal rights were to receive the special protection of the removal provision. ${ }^{24}$

Similarly, problems with interpreting the phrase rights "denied or cannot enforce" did not really arise until after 1875. The 1866 Act had declared that removal procedures would follow those of the Habeas Corpus Suspension Act of 1863, which authorized removal either before or after trial in the state court. ${ }^{25}$ At least with regard to post-trial removal the district court was not placed in a position of having to predict the behavior of the state court in order to determine whether a defendant would be denied or unable to enforce a particular right in that court; it could look to the trial to determine whether rights had been denied. ${ }^{26}$ However, in 1875 Congress eliminated post-trial removal, ${ }^{27}$ leaving it to the Supreme Court to determine the scope of pre-trial removal under the remaining provisions.

Originally the Supreme Court was denied the opportunity to determine the limits of pre-trial removal because an order to remand to the state courts was considered to be a non-final order and thus not subject to appeal. ${ }^{28}$ This bar was lifted in 1875 when Congress passed a statute making a remand order reviewable on appeal. ${ }^{29}$ In a series of decisions referred to as the Strauder-Powers cases, ${ }^{30}$ the Court interpreted the removal provision narrowly, allowing removal before trial only when the defendant could point to a state statute or constitutional provision discriminatory on its face. ${ }^{31}$ The first two decisions in this line set

23 The substantive guarantees contained in $\$ 1$ were codified in REv. STAT. \$\$ 1977-78 (1875), presently 42 U.S.C. $\$ \S 1981-82$ (1970), and the removal provisions of $\S 3$ were codified in REv. STAT. \& 641 (1875), presently 28 U.S.C. \$ 1443 (1970).

24 See New York v. Galamison, 342 F.2d 255 (2d Cir.), cert. denied, 380 U.S. 977 (1965) (discussing § 1443(2)); Amsterdam, supra note 11, at 863-74; Note, Federal Jurisdiction: The Civil Rights Removal Statute Revisited, 1967 DUKE L. REv. 136, 151-71.

25 Habeas Corpus Suspension Act of March 3, 1863, ch. 81, § 5, 12 Stat. 756, as amended, Act of May 11, 1866, ch. 80, \& 3, 14 Stat. 46 .

26 It would seem, however, that even with post-trial removal there is an element of prediction, for permitting removal assumes that the federal right could not be vindicated through an appeal within the state court system.

27 A removal petition could be filed "at any time before the trial or final hearing of the cause." REv. STar. \$ 641 (1875). See Amsterdam, supra note 11, at 843 n.201.

28 See Lusky, Racial Discrimination and the Federal Law: A Problem in Nullification, 63 Colum. L. Rev. 1163, 1189-90 \& n.108 (1963).

29 Act of March 3, 1875, ch. 137, § 5, 18 Stat. 472.

30 Kentucky v. Powers, 201 U.S. 1 (1906) ; Williams v. Mississippi, 170 U.S. 213 (1898); Murray v. Louisiana, 163 U.S. 101 (1896); Smith v. Mississippi, 162 U.S. 592 (1896); Gibson v. Mississippi, 162 U.S. 565 (1896); Bush v. Kentucky, 107 U.S. 110 (1883); Neal v. Delaware, 103 U.S. 370 (1881); Virginia v. Rives, 100 U.S. 313 (1880); Strauder v. West Virginia, 100 U.S. 303 (1880).

31 In each of the cases in this line it was a state statute regulating trial procedure that was found unconstitutional, requiring removal. Logic would, however, dictate the same result when it is the state criminal statute underlying the prosecution that is 
the tone for those to follow. In Strauder v. West Virginia ${ }^{32}$ removal was granted because an applicable state statute disqualified blacks from sitting on grand or petit juries. But removal was denied in Virginia $v$. Rives $^{33}$ despite uncontradicted allegations that no black had ever served on a county jury, because the petitioners could point to no statutory or constitutional provisions of the state authorizing this practice. The Court reasoned that in the absence of such a discriminatory statute a defendant could not predict with certainty that his equal rights would be denied. ${ }^{34}$

It is to be observed that that act gives the right of removal only to a person "who is denied, or cannot enforce, in the judicial tribunals of the State his equal civil rights." And this is to appear before trial. When a statute of the State denies his right, or interposes a bar to his enforcing it, in the judicial tribunals, the presumption is fair that they will be controlled by it in their decisions; and in such a case a defendant may affirm on oath what is necessary for a removal. ${ }^{35}$

This approach had the practical virtue of providing a clear test which did not require a federal judge to anticipate the conduct of a particular state court.

In 1887 Congress repealed the legislation making remand orders appealable, ${ }^{36}$ and it was not until the enactment of the Civil Rights Act of 1964 that Congress again made it possible for the Supreme Court to interpret the scope of civil rights removal. ${ }^{37}$ Section 901 of that Act provided that cases removed under section 1443 were exempt from the general statutory provisions making remand orders nonreviewable. ${ }^{38}$

\section{The 1966 Supreme Court Cases}

The issue before the Supreme Court in Georgia v. Rache ${ }^{39}$ and City of Greenwood v. Peacock ${ }^{40}$ was whether the district court should have held a hearing on the allegations made in a section 1443 removal

unconstitutional. Facially unconstitutional statutes, whether substantive or procedural, deny defendants federally guaranteed rights and can result in illegal convictions. See Amsterdam, supra note 11, at 852. See also Georgia v. Rachel, 384 U.S. 780, 800, 803 (1966) (discussing the early cases without drawing a distinction between substantive and procedural statutes).

32100 U.S. 303 (1880).

33100 U.S. 313 (1880).

34 Id. at 320.

35 Id. at 321.

36 Act of March 3, 1887, ch. 373, § 2, 24 Stat. 553.

37 But see Amsterdam, supra note 11, at 832-33 n.173. Although no immediate appeal was possible, the Court could have considered the scope of civil rights removal jurisdiction in an appeal from a state conviction in a case that a federal district court had remanded following removal.

38 See note 6 supra.

39384 U.S. 780 (1966).

40384 U.S. 808 (1966). 
petition. The defendants in Rachel were prosecuted under a Georgia criminal trespass statute making it a misdemeanor to fail to leave another person's premises after having been ordered to do so by the owner or his agent. ${ }^{41}$ The removal petitions alleged that the defendants had been seeking to obtain service at a restaurant and had refused the proprietor's request that they leave the premises. In the removal petition the defendants further alleged that their arrests and prosecutions "were effected for the sole purpose of aiding, abetting, and perpetuating customs ... which exist within the City of Atlanta with respect to serving and seating members of the Negro race in such places of public accommodation and convenience upon a racially discriminatory basis . ..."

The Court first concluded that the phrase, "any law providing for ... equal civil rights," was not meant to include only the Civil Rights Act of $1866 .^{43}$ Nor was the phrase limited to include only civil rights statutes in effect in 1875, the date of the codification which first used that phrase. Rather, said the Court, Congress intended to include all statutes of a nature similar to that of the 1866 Act, including all such statutes to be enacted in the future. ${ }^{44}$ In order to come within the scope of the removal statute, a law must, according to Rachel, provide "for specific civil rights stated in terms of racial equality." Under this formulation the deprivation of first amendment or due process guarantees is insufficient to support removal since they are phrased generally and are available to all persons. ${ }^{46}$ But the Civil Rights Act of 1964 was found to be a "law providing for . . . equal civil rights" since in section 201(a) it guaranteed to every person the "full and equal enjoyment ... of any place of public accommodation ... without discrimination or segregation on the ground of race, color, religion, or national origin." 47

In the absence of a discriminatory state statute removal could not have been granted under the Strauder-Powers decisions. The Court, however, managed to expand the scope of section 1443(1) without significantly undercutting those cases. This was accomplished by emphasizing three words in the language of Virginia v. Rives:

In Rives itself, however, the Court noted that the denial of which the removal provision speaks "is primarily, if not

11384 US. at $783 \&$ n.1.

42 Id. at 783.

43 Id. at $788-92$.

44 Id. at 792 .

45 Id. See Note, supra note 24, at 151-71.

46 Georgia v. Rachel, 384 U.S. 780, 792 (1966). The Court did not deal with the status of the equal protection clause. The question is whether a constitutional provision is a "law." See id. at 790 n.13.

47 Id. at $792-93$ \& n.20. 
exclusively, a denial ... resulting from the Constitution or laws of the State ...." 100 U.S., at 319. (Emphasis supplied.) . . . The Court thereby gave some indication that removal might be justified, even in the absence of a discriminatory state enactment, if an equivalent basis could be shown for an equally firm prediction that the defendant would be "denied or cannot enforce" the specified federal rights in the state court. $^{48}$

The Court said that it was able to make such a prediction in Rachel on the basis of the Civil Rights Act of $1964 .^{49}$ Section 201(a) of that act guaranteed to all persons the right of equal access to places of public accommodation without regard to race or color. Furthermore, section 203 provided that "[n]o person shall ... (c) punish or attempt to punish any person for exercising or attempting to exercise any right or privilege secured by section 201 or $202 .{ }^{250}$ That provision had been interpreted in Hamm v. City of Rock Hill ${ }^{51}$ to prohibit not only the conviction, but the very act of prosecution, of individuals for conduct authorized by section $201 .^{52}$ The Rachel defendants were being prosecuted under a Georgia trespass statute which made it a misdemeanor for a person to refuse to leave another's premises upon the request of the owner. ${ }^{53}$ Thus, if the removal petition's allegations were true, then "the defendants refused to leave facilities of public accommodation, when ordered to do so solely for racial reasons," mere prosecution of the defendants for failure to obey that order a denial of a right conferred by the 1964 Civil Rights Act. The 1964 Act, as interpreted in Hamm, "substitutes a right for a crime."

Hence, if as alleged in the present removal petition, the defendants were asked to leave solely for racial reasons, then the mere pendency of the prosecutions enables the federal court to make the clear prediction that the defendants will be "denied or cannot enforce in the courts of [the] State" the right to be free of any "attempt to punish" them for the protected activity. It is no answer in these circumstances that the defen-

48 Id. at 804.

49 Civil Rights Act of 1964, Pub. L. No. 88-352, \$\$ 201-03, 78 Stat. 243, 42 U.S.C. $\S \S 2000$ a to a-2 (1970). There is at least some legislative history indicating that Congress intended such a result. See Note, supra note 24 , at 160 n.122.

5042 U.S.C. \& 2000a-2 (1970).

61379 U.S. 306 (1964).

52 Id. at 311. From this discussion in $\mathrm{Hamm}$ it is not entirely clear that all prosecutions, inciuding unsuccessful ones, were prohibited. In Rachel, however, this possible ambiguity was resolved; the Court read $\mathbf{H a m m}$ to prohibit the very act of prosecution. 384 U.S. at 794.

53384 U.S. at 783 \& n.1.

54 Id. at 804.

55 Hamm v. City of Rock Hill, 379 U.S. 306, 314 (1964), quoted in Georgia v. Rachel, 384 U.S. 780, 805 (1966). 
dants might eventually prevail in the state court. The burden of having to defend the prosecutions is itself the denial of a right ....58

The Court found that this type of firm prediction could not be made in City of Greenzood v. Peacock. ${ }^{57}$ Peacock consisted of two separate cases. One set of petitioners was charged with the misdemeanor of obstructing the public streets. They alleged that they were members of a civil rights group engaged in a voter registration drive, and that the arrests and prosecutions were racially motivated. ${ }^{58}$ The second group of petitioners, also civil rights group members, had been charged with a variety of offenses including assault, parading without a permit, reckless driving, and profanity. ${ }^{59}$ They alleged that their arrests and prosecutions were for the "sole purpose and effect of harassing" them and that "they had been denied and could not enforce ... rights under laws providing for equal civil rights . . . because of the commitment of the courts and [law enforcement] officers to the State's declared policy of racial segregation." take place in a segregated courtroom before judges and prosecutors who had gained office in elections from which Negro voters had been excluded, and that Negroes would also be excluded from the juries. ${ }^{61}$

Denying removal, Justice Stewart found an "immediately apparent" difference between this case and Rachel:

In Rachel the defendants relied on the specific provisions of a preemptive federal civil rights law ... that, under the conditions alleged, gave them: (1) the federal statutory right to remain on the property of a restaurant proprietor after being ordered to leave, despite a state law making it a criminal offense not to leave, and (2) the further federal statutory right that no State should even attempt to prosecute them for their conduct. The Civil Rights Act of 1964 as construed in Hamm thus specifically and uniquely conferred upon the defendants an absolute right to 'violate' the explicit terms of the state criminal trespass law with impunity under the conditions alleged in the Rachel removal petition, and any attempt by the State to make them answer in a court for this conceded "violation" would directly deny their federal right "in the courts of [the] State." The present case differs from Rachel in two significant respects. First, no federal law confers an absolute right on private citizens-on civil rights advocates, on $\mathrm{Ne}$ groes, or on anybody else- to obstruct a public street, to con-

56384 U.S. at 805 (footnote omitted).

57384 U.S. 808 (1966).

$58 I d$. at $810-12 \&$ n.3.

59 Id. at $813 \&$ n.5.

60 Id. at 813 \& n.6.

61 Id. at 813 n.6. 
tribute to the delinquency of a minor, to drive an automobile without a license, or to bite a policeman. Second, no federal law confers immunity from state prosecution on such charges. ${ }^{82}$

This analysis fails to distinguish satisfactorily the two cases and has created a morass for the lower federal courts. For although no statute gives anyone the absolute right to bite a policeman, it is equally true that no federal law confers an absolute right for anyone, including the Rachel defendants, to trespass. The Rachel defendants had a right to remain on the premises only if the order to leave was racially motivated in violation of the Civil Rights Act of 1964. The Court ordered the district court to hold a hearing on this question. The Peacock defendants, if granted such a hearing, might also have been able to prove that they were being prosecuted solely for the exercise of federally protected activity. As will be discussed, ${ }^{63}$ sections 1971 (b) and 1973 (i) (b) could provide the Peacock defendants with the same immunity from prosecution that resulted in the Rachel decision. Here, too, the very act of prosecution could, under the removal petition's allegations, constitute a denial of federally protected rights.

The unsatisfactory nature of the Court's opinions has forced the lower federal courts to search for an unarticulated distinction between Rachel and Peacock. ${ }^{64}$ Three basic questions have arisen in the cases which have confronted the courts of appeals since 1966. First, what wording is necessary in a federal statute providing for equal civil rights before it is sufficient to confer immunity from prosecution as well as conviction? Rachel relies on section 203(c) of the Civil Rights Act of 1964 which, under stated circumstances, prohibits an "attempt to punish." Some other civil rights statutes ${ }^{65}$ within the meaning of section 1443 (1)'s "equal civil rights" requirement ${ }^{66}$ protect individuals against any "attempt to intimidate, threaten, or coerce" them because of their exercise of rights conferred by that statute. Arguably, this language, present in the voting rights bill relied upon by the petitioners in Peacock does not provide the necessary prophylactic federal statute. Unlike the term "punish," the phrase "intimidate, threaten, or coerce" may not apply to prosecutions brought by the state. ${ }^{67}$

Second, in passing upon a removal petition, should the federal district judge look to the allegations in the removal petition, those of the

62 Id. at $826-27$.

63 Text accompanying notes 71-85 infra.

64 This is particularly important because after Rachel it is most unlikely that a case will duplicate the Rachel facts, because state prosecutors can carefully choose the time of arrest and the crime charged if they are trying to harass a civil rights worker. See Frinks v. North Carolina, 468 F.2d 639, 647 (4th Cir. 1972) (Sobeloff, J., dissenting).

6542 U.S.C. $\$ \S 1971(\mathrm{~b}), 1973 i(\mathrm{~b})(1970)$.

68 See text accompanying notes $43-47$ supra.

67 See notes 71-79 infra \& accompanying text. 
criminal charge or indictment, or both? In Rachel the Court accepted the petitioners' allegations concerning the racial motivation of the restaurant owner. But if the petitioners were being prosecuted for assaulting the restaurant manager after refusing his order to leave, and they alleged that no violence of any type had occurred, and that they were being prosecuted solely for their failure to leave, the question as to which set of allegations is determinative, becomes crucial. For if the criminal charge is controlling, then no right established by the Civil Rights Act of 1966 would appear to be violated by the very act of prosecution, and remand to the state court without a hearing would be appropriate.

The third question only arises if it is decided that the federal district judge should look, at least in part, to the allegations in the removal petition. What type of causal connection must be alleged in a removal petition to link the prosecution and the civil rights activity which allegedly gives rise to that prosecution? If, for example, a defendant alleges that his prosecution for reckless driving is solely motivated by his civil rights activity earlier that day, should a factual hearing be held? Should it matter that the civil rights activity took place three weeks before the arrest? Should murder or larceny charges be treated differently than reckless driving or vagrancy?

These questions will first be analyzed in the context of the attempts by the courts of appeals to deal with Rachel and Peacock.

\section{Rachel AND Peacock Distinguished IN THE COURTS OF APPEALS}

The Supreme Court reached divergent results in Rachel and Peacock without making clear which case established the general principle and which merely the exception. ${ }^{68}$ This ambiguity has become manifest in the removal decisions in the courts of appeals, where the practice has been to rely upon Rachel and explain away Peacock when granting removal and to follow the reverse procedure when ordering remand to the state trial court. In at least one decision the court relied on Peacock without even mentioning $R a c h e l .{ }^{69}$ At least four different analyses have been offered to explain the Supreme Court's decisions.

68 Regarding Rachel, the Fifth Circuit has said: "It has always been the position of the court that unless the Supreme Court expressly limits its opinion to the facts before it, it is the principle which controls and not the specific facts upon which the principle was decided." Walker v. Georgia, 417 F.2d 5, 8 (5th Cir. 1969). However, this same court of appeals has read Peacock, also not limited to its facts by the Supreme Court, to have been decided upon a particular factual issue not even expressly mentioned in the Court's opinion. See text accompanying notes $80-81$ infra.

Judge Godbold, speaking of a plaintiff whose arrest he deemed a "flagrant wrong" on a "baseless" vagrancy charge, stated without providing any reasons: "Factually [the petitioner] is somerwhere between [Rachel] and [Peacock]. But her case is removable only if it is within Rachel." Achtenberg v. Mississippi, 393 F.2d 468, 475-76 (5th Cir. 1968) (concurring in part and dissenting in part).

69 Perkins v. Mississippi, 455 F.2d 7 (5th Cir. 1972). 
Judge Sobeloff has interpreted Rachel and Peacock in a manner which would limit removal to cases in which the petitioner invoked section 203 (c) of the Civil Rights Act of $1964^{70}$ in support of his removal petition. ${ }^{71}$ The Peacock defendants had based their removal petition on section 1971(b), which declares:

No person, whether acting under color of law or otherwise, shall intimidate, threaten, coerce, or attempt to intimidate, threaten, or coerce any other person for the purpose of interfering with the right of such other person to vote . . . ${ }^{72}$

Judge Sobeloff relied on this language in distinguishing Rachel and Peacock. Under his analysis the Peacock Court's statement that "no federal law confers immunity from state prosecution" was based on the failure of section 1971(b) to specifically prohibit actions which "punish or attempt to punish." ${ }^{\prime \prime 3}$ Under this approach civil rights workers involved in protecting the right to public accommodations would have access to the federal courts but those attempting to vote or to register others to vote ${ }^{74}$ would not. Judge Sobeloff felt bound by what he considered the Supreme Court's interpretation of section 1971(b) despite his belief that its language "is a more, not less, sweeping prohibition of official acts of harassment against equal civil rights than the limited proscription of $\S 203$ (c), since 'attempts to punish' are only one means of coercing, threatening, or intimidating." cock assumes that the Court's statement regarding the lack of a federal right is based on the inherent failing of that statute rather than on its failure to protect the conduct charged by the state. He ignores the last three words of the sentence he quotes. Justice Stewart's full sentence was: "Second, no federal law confers immunity from state prosecution on such charges." ${ }^{\text {" }}$ It is difficult to believe that the Court

7042 U.S.C. \& 2000a-2 (1970).

71 Frinks v. North Carolina, 468 F.2d 639, 645 (4th Cir. 1972) (dissenting opinion); North Carolina v. Hawkins, 365 F.2d 559, 560 (4th Cir.) (concurring opinion), cert. dented, 385 U.S. 949 (1966).

7242 U.S.C. $\S 1971$ (b) (1970).

73 Frinks v. North Carolina, 468 F.2d 639, 646 (4th Cir. 1972) (dissenting opinion); North Carolina v. Hawkins, 365 F.2d 559, 562-63 (4th Cir.) (concurring opinion), cert. denied, 385 U.S. 949 (1966).

Originally the Second Circuit, in dictum by Judge Friendly, rejected this analysis. New York v. Davis, 411 F.2d 750, 753 (2d Cir.), cert. denied, 396 U.S. 856 (1969) (hypothetical removal case under 42 U.S.C. \& 3617 (1970)). In a more recent opinion, however, the court, in another opinion by Judge Friendly, indicated that it was no longer certain that Judge Sobeloff's analysis was incorrect, but under the circumstances did not have to decide the issue. New York v. Horelick, 424 F.2d 697, 702-03 n.4 (2d Cir.), cert. denied, 398 U.S. 939 (1970).

74 See 42 U.S.C. $\$ \S 1971(b), 1973 i(b)$ (1970). See also text accompanying notes 80-82 infra.

75 North Carolina v. Hawkins, 365 F.2d at 562. After analyzing the language of $\S 1971$ (b) and concluding that it "performs the same function as $\S 203$ (c), and ... should be given the same effect," Judge Sobeloff remarked that "[i]t is difficult to conceive that Congress intended to place voting rights guarantees on a lower plane of protection than the right to equal public accommodations." Id. at 562 n.7.

76 City of Greenwood v. Peacock, 384 U.S. 808, 827 (1966). 
would have denied removal to the Peacock defendants if they had been prosecuted for trespassing in the voting registrar's office-such an office not being within the 1964 Civil Rights Act's definition of a "place of public accommodations"77 — and had alleged that they had been attempting to register at the time of their arrest and that they were being prosecuted solely for that activity, activity within the protection of section 1971(b). ${ }^{78}$ For this reason, and since the "attempt to intimidate, threaten, or coerce," language is broad enough to include state prosecutions, the difference in statutory language does not satisfactorily account for the divergent results in Rachel and Peacock. ${ }^{79}$

A second line of analysis has been provided by the Fifth Circuit which has read the Supreme Court cases in a manner that makes Peacock a quirk rather than a precedent. That court has relied on the timing of enactment, rather than the scope of the federal statutes involved in Rachel and Peacock, as a means of distinguishing the two cases. ${ }^{80}$ Its approach reads $R a c h e l$ very broadly without attaching any inherent limitation to the immunization power of the "intimidate, threaten, or coerce" language present in section 1971(b). Judge Tuttle, speaking for the court in Whatley $v$. City of Vidalia, ${ }^{81}$ noted that section 1971(b) refers only to voters but the Peacock defendants had alleged only that they were arrested for encouraging other persons to register. Only after their petitions were filed and while their cases were on appeal, did Congress enact section $1973 \mathrm{i}(\mathrm{b})$ as part of the

7742 U.S.C. $\$ 2000 \mathrm{a}$ (b) (1970).

78 Cf. New York v. Davis, 411 F.2d 750, 753 (2d Cir.), cert. denied, 396 U.S. 856 (1969).

79 Another question of statutory language arises when the petitioner relies on title I of the 1968 Civil Rights Act, 18 U.S.C. \$ $245(\mathrm{~b})$ (1970). That statute provides criminal penalties for " $[w]$ hoever . . by force or threat of force willfully injures, intimidates, or interferes with, or attempts to injure, intimidate or interfere with" any citizen because of his exercise of certain rights including the right to apply for or enjoy employment. Id. (emphasis added). The Second and Third Circuits have both held that prosecutions which interfere with the exercise of this right to equal employment are not removable because the term "force" in the statute limits its protection to physical violences, and therefore does not protect against state prosecutions whatever the motive. New York v. Horelick, 424 F.2d 697 (2d Cir.), cert. denied, 398 U.S. 939 (1970); Hill v. Pennsylvania, 439 F.2d 1016, 1022 (3d Cir.), cert. denied, 404 U.S. 985 (1971) (alternative holding).

Judge Brown has strongly attacked this limited reading of the 1968 Act. For his conclusion that "force" is a far broader term than "violence" he relies both on the legislative history of title I and "the fact that arrest, confinement and criminal prosecution are all inherently coercive in nature (and therefore invariably entail utilization of 'threats of force'). . . Perkins v. Mississippi, 455 F.2d 7, 40-41 (5th Cir. 1972) (dissenting opinion). He goes on to state that

[t]o exclude harassing criminal prosecutions from the scope of $\S 245(\mathrm{~b})$ 's immunity simply because beatings and killings may have provided the primary impetus for its enactment is to pay homage to the right while eviscerating the remedy. The ultimate consequence of intimidation is the same, whether the Id. at 41 . victim is in jail, in the hospital or in the grave.

80 Whatley v. City of Vidalia, 399 F.2d 521 (5th Cir. 1968); see Davis v. Alabama, 399 F.2d 527 (5th Cir. 1968). But cf. Perkins v. Mississippi, 455 F.2d 7 (5th Cir. 1972). After this Comment was set into print, the Fifth Circuit, upon rehearing en banc, reached the same result as had the panel. Perkins v. Mississippi, No. 30,410 (Dec. 20, 1972) (mem.).

81399 F.2d 521 (5th Cir. 1968). 
Voting Rights Act of 1965, thereby extending protection to those helping others to vote or register, as well as those who are themselves voting. Consequently, the argument goes, the Supreme Court did not reach the question of the prophylactic effect of statutory language prohibiting any attempt to "intimidate, threaten, or coerce", since the petitioners' conduct was not subject to federal statutory equal rights protection at the time of their arrest. ${ }^{82}$ This line of analysis is clearly unacceptable as a basis for distinguishing Rachel and Peacock since two factors indicate that the majority did take section $1973 \mathrm{i}(\mathrm{b})$ into consideration. ${ }^{83}$ First, the same footnote which quotes the provisions protecting voters in section 1971 (b) also cites, without discussion, section $1973 \mathrm{i}(\mathrm{b}) .^{84}$ If this distinction was the basis for the Peacock decision, the Court's citation to the statute at that point in the opinion, without further explication, could only be interpreted as intentional obscurity. Second, this argument proves far too much for it would have also resulted in removal being denied in Rachel. The Rachel petitioners did not invoke the public accommodations provisions of the Civil Rights Act of 1964 in their removal petition because that equal rights statute also had not been enacted. It became law while the case was on appeal ${ }^{85}$ and the Supreme Court applied its provisions to make a clear prediction that the maintenance of a trial would violate the statute. If section $1973 \mathrm{i}(\mathrm{b})$ could ever insulate the defendants in factual situations similar to Peacock, then it would have permitted removal in Peacock itself, in the same manner that section 2000a-2 required removal in Rachel. For at the time the Peacock Court remanded to the state court for trial, section $1973 \mathrm{i}(\mathrm{b})$ was in effect, and, under this analysis, should have protected the Peacock defendants.

The Third Circuit has read Rachel very narrowly. Relying on the fact that in Rachel the state criminal statute purported to punish the same specific conduct which the federal statute claimed to protect, while no such direct conflict occurred between the federal statute relied upon by the Peacock defendants and the criminal statute under which they were prosecuted, Judge Seitz stated:

The statutes relied upon in Rachel necessarily displaced any state laws which would proscribe the act of remaining in public accommodations when asked to leave on account of race by prohibiting attempted punishment for this act. However, when statutes, such as those relied upon in Peacock, grant one a right not to be intimidated for efforts to accomplish a particular goal or while asserting a specific right, we cannot ascribe to Congress an intent to displace state laws which

82 Id. at 522-24.

$83 \mathrm{~A}$ third indication is that the dissent considered this statute. City of Greenwood v. Peacock, 384 U.S. 808, 847-48 (Douglas, J., dissenting, with whom Warren, C.J., and Brennan \& Fortas, JJ., concurred).

84384 U.S. at 811 n.3.

85 Georgia v. Rachel, 384 U.S. 780, 785 (1966). 
regulate one's conduct while attempting to exercise the right unless, of course, the federal right permits specific acts which are proscribed by state law, or the state law, in effect, forecloses a reasonable possibility of engaging in acts necessary to assert the federal right. ${ }^{86}$

Thus, removal in the Third Circuit is determined primarily on the basis of the statute which forms the basis of the state's charge. The allegations of the removal petition are relevant on the question whether remand is proper or a factual hearing should be held by the district court only to the extent they allege improper motivation is presentmotivation which would bring the state statute into direct conflict with the prophylactic federal civil rights statute.

In New York v. Davis, ${ }^{87}$ the Second Circuit distinguished Rachel and Peacock in a similar manner. The court relied on the Supreme Court's finding that no federal law conferred immunity from the generally applicable state criminal statutes involved in Peacock despite the petitioner's allegations that the prosecutions were intended to interfere with protected rights. Judge Friendly concluded:

The line is thus between prosecutions in which the conduct necessary to constitute the state offense is specifically protected by a federal equal rights statute under the circumstances alleged by the petitioner, and prosecutions where the only grounds for removal are that the charge is false and motivated by a desire to discourage the petitioner from exercising or to penalize him for having exercised a federal right. ... To apply this distinction requires the court to scrutinize the state criminal statute and the charge thereunder as well as the factual allegations in the removal petition, since removal is not authorized if the petition simply denies facts that would be essential to a conviction . . . and alleges improper motivation. . . Putting the matter in a slightly different way, whereas the Civil Rights Act of 1964 had rendered Georgia's refusal to leave on demand statute unconstitutional in cases where the demand was racially motivated, the Fair Housing Act has not rendered New York's "menacing" statute unconstitutional simply because the defendant claims that the prosecution is basely motivated and that he did not do what has been charged. ${ }^{88}$

Thus the criminal charge and the supporting statute are also crucial

86 Hill v. Pennsylvania, 439 F.2d 1016, 1021 (3d Cir.), cert. denied, 404 U.S. 985 (1971). In a recent case the Fourth Circuit adopted this same analysis. Frinks v. North Carolina, 468 F.2d 639, 642 (4th Cir. 1972) ("The federal law [relied upon in Rachel] invalidated the Georgia trespass statute, at least where the request to leave was invidiously motivated, and substituted 'a right for a crime." ") See North Carolina v. Hawkins, 365 F.2d 559 (4th Cir.), cert denied, 385 U.S. 949 (1966).

87 New York v. Davis, 411 F.2d 750 (2d Cir.), cert. denied, 396 U.S. 856 (1969).

$88 \mathrm{Id}$. at 754. It is no longer clear that this is the Rachel-Peacock line in the Second Circuit. See note 73 supra \& accompanying text. 
considerations in the Second Circuit. This test focuses on the "conduct necessary to constitute the state offense," and is therefore essentially the same as that of the Third Circuit. ${ }^{89}$ Only when, under the facts of the case as indicated by the petitioner's allegations, the state criminal statute will be brought into direct conflict with a "supreme" federal equal rights statute, will a factual hearing be proper on motion to remand. In all other situations remand to the state trial court will be made without an evidentiary hearing.

Judge Brown, in a dissent, ${ }^{90}$ has expressed his belief that the key to the cases is the statement in Peacock that removal could not be sustained "upon the allegations of the petitioners in this case . . . ." Under this interpretation the Peacock defendants had not been entitled to removal because they had failed to allege that they were being prosecuted solely for their exercise of federally protected activity. Removal was improper because under their allegations it was possible that they were being prosecuted both for their protected activity and for violating valid state statutes. Thus, Judge Brown would require a factual hearing in the federal district court any time the defendant alleged in his removal petition that he was being prosecuted exclusively because of his exercise of federally protected rights.

There are several problems with this analysis. First, the removal petitions of the second group of Peacock defendants, as quoted by the Supreme Court, alleged that they were being prosecuted for the "sole purpose and effect of harassing Petitioners and of punishing them for and deterring them from the exercise of their constitutionally protected right to protest the conditions of racial discrimination and segregation .... . 202 Secondly, this analysis relies totally on one phrase in Peacock, without accounting for the remainder of the opinion. ${ }^{93}$ Thirdly, it assumes that the reference to "upon the allegations" indicates that different factual allegations as to one particular fact was the cause of the remand. But the Court's reference to the allegations does not necessarily imply that its concern was with the facts alleged. This reference to the allegations is equally consistent with the narrower conclusions of the Second and Third Circuits. Since the conduct re-

89 The Second Circuit did leave some room for possible expansion in the Davis decision. A footnote points out that the facts did not require the court to decide the issue of "whether, despite what seems to be the contrary thrust of Peacock, a prosecution may be removable under $\S 1443(1)$ if the defendant claims he was engaged in conduct so closely related to that protected by the federal equal rights statute that the criminal charges are only "convenient tags." $411 \mathrm{~F} .2 \mathrm{~d}$ at 754 n.4. See also note 73 supra \& accompanying text.

90 Perkins v. Mississippi, 455 F.2d 7, 11 (5th Cir. 1972) (dissenting opinion).

91 Id. at 26 (quoting City of Greenwood v. Peacock, 384 U.S. 808, 827 (1966)) (emphasis omitted).

92 City of Greenwood v. Peacock, 384 U.S. 808,813 (1966); see id. at 828 ("If, as they allege, they are being prosecuted on baseless charges solely because of their race, then there has been an outrageous denial of their federal rights . ....").

93 Id. at 826-27. 
quired for conviction on the state charge was not protected by a federal statute ${ }^{94}$ the petitioners' allegations were indeed insufficient, but nothing they could have alleged under the circumstances would have altered the Court's result. Finally, this analysis leads to a test at variance with the Peacock Court's concerns about overburdening the federal judiciary and increasing delay, and its desire not to repudiate the teachings of the Strauder-Powers decisions. ${ }^{95}$

\section{A Broad Test and the Question of Causation}

A civil rights worker attempting to integrate a public restaurant is charged with assaulting the manager during that attempt. A black person is charged with disturbing the peace a few minutes after he left a restaurant which grudgingly served him food. Three days after he attempted to gain service in a restaurant a black person is arrested for speeding or bank robbery. Each of these people removes his case to the federal district court alleging that he is being prosecuted solely because of his exercise of federally protected rights. On the state's motion to remand should the federal district judge hold a factual hearing?

Under the test propounded by the Second and Third Circuits no such question need be asked. Since the conduct necessary for conviction under the state statute is not specifically insulated by a federal equal rights law (and since the state statute does not inherently foreclose activity necessary for the assertion of a right under the federal law), there are no factual questions to be resolved at a hearing, and the district judge will remand to the state trial court.

But under any other reading of Rachel and Peacock this question will inevitably arise. This is true even under Judge Sobeloff's analysis that the cases are explained by the "attempt to punish" language present in section 2000a-2 but not in section 1971(b). ${ }^{96}$ That approach limits removal to cases in which the right exercised relates to public accommodations, but it does not require the state criminal charge to be trespass or the like. Rather, whatever the charge, if the defendant alleges that the prosecution is actually for protected activity then a hearing is necessary. ${ }^{97}$ Similarly, under the explanations of Rachel and Peacock offered by the Fifth Circuit in Whatley, and by Judge Brown's dissent, these questions arise. They are essentially questions of causation, or, regarding the question of whether an evidentiary hearing should be held, a question as to the relationship between the state's criminal charge and the federally protected activity engaged in by the defendant.

94 See text accompanying notes 86-89 supra.

95 See text accompanying notes 121-31 infra.

96 See notes 71-79 supra \& accompanying text.

97 Frinks v. North Carolina, 468 F.2d 639, 647-48 (4th Cir. 1972) (dissenting opinion); North Carolina v. Hawkins, 365 F.2d 559, 561 (4th Cir.) (concurring opinion), cert. denied, 385 U.S. 949 (1966). 
The only clear case ${ }^{98}$ is one like Rachel in which the state statute explicitly punishes an activity that is immunized from prosecution by a federal equal rights statute under the facts alleged in the removal petition. And it should not matter that the state specifically denies that, for example, a request to leave was racially motivated. Even if the state claims that the defendant was asked to leave because of his failure to wear shoes, this is basically the motivation question on which the Rachel Court ordered an evidentiary hearing. ${ }^{99}$ For, under the facts of the case as alleged in the removal petition, not only are the defendants being harassed for their protected activity, but the state statute, by its own terms, is in direct conflict with the federal statute.

The difficulties arise when the state and federal statutes do not come into conflict but the defendant claims that he is being prosecuted because of his protected activity.The strongest argument for removal in such a case occurs where the defendant is in the process of exercising his federal rights when he is arrested under a broad criminal statute such as a vagrancy or disorderly conduct law. If Rachel is not to be limited to its facts, this type of case presents the strongest arguments for removal. First, the defendants are being prosecuted under a broadly worded statute of a type which is easily used to harass. Removal is particularly important for prosecutions under such statutes because it is more likely that a prosecutor could successfully convince a jury that the defendant's behavior was essentially "bad" and should be punished, than that a jury would convict erroneously on a more specific-and more serious-charge. Furthermore, a conviction on a general charge is less likely to be reversed for insufficient evidence on appeal because the reviewing court will be less able to look to one particular fact as the basis for decision. ${ }^{100}$ Second, although there is no accord between the parties as to the basis for the arrest, the alleged protected activity coincides with the time and place of arrest. This is not a situation where the petitioner claims that his arrest was caused by his protected activity earlier that day or some other day. Thus, if an evidentiary hearing is held, it is not necessary to connect two seemingly unrelated events in

98 The discussion in this section focuses on cases in which the defendant claims that he is being prosecuted for activity protected by the "attempt to punish" language of the Civil Rights Act of 1964, thus removing the issue of what language is necessary in federal equal rights statutes to immunize conduct from valid state criminal laws. See notes $43-47$ supra \& accompanying text.

99 In Rachel the state did not specifically allege a different motive for the manager's request that the defendants leave, but there were no stipulated facts, or specific acceptance of the defendants' claim, and the Supreme Court treated it as a disputed question, ordering a hearing for the purpose of giving the defendants an "opportunity to establish that they were ordered to leave the restaurant facilities solely for racial reasons." Georgia v. Rachel, 384 U.S. 780, 805 (1966). See also New York v. Davis, 411 F.2d 750, 754 (2d Cir.), cert. denied, 396 U.S. 856 (1969) (authorizing removal when "the conduct necessary to constitute the state offense is specifically protected by a federal equal rights statute under the circumstances alleged by the petitioner ...." (emphasis added)).

$100 \mathrm{Cf}$. Amsterdam, supra note 11, at 857-58 ("Where removal is most needed is the case in which the impingement on federal rights is more subtle, more immune against appellate correction ...."). 
order to show that the prosecution was an attempt to punish protected activity.

In Achtenberg v. Mississippi the Fifth Circuit expounded on the subject of broad state criminal statutes:

There is no magic in the word "trespass" as a basis for limiting the effect of the Supreme Court's decision in Rachel. "Trespass" in Georgia is a broad enough charge to cover illegal entry on the property of another without regard to any questions of race or color; or it could also cover merely the refusals of a person to leave public accommodations because of a policy of racial exclusion. The movants alleged in Rachel that it was the latter. Thus that allegation, the Court held, asserted a ground for removal, and that allegation must be proven if challenged. So, too, the vagrancy statute may be a convenient tag for the state of Mississippi to attach to this conduct of these movants. ${ }^{101}$

The concern of the court is to make it impossible for the state prosecutor to defeat federal jurisdiction by the simple expedient of charging the defendants with a crime other than trespass. ${ }^{102}$ But this concern can not be limited to prosecutions under broad criminal statutes such as disorderly conduct and vagrancy. Prosecutors can also "attempt to punish" civil rights activists by charging them with assault, possession of a deadly weapon, or robbery. Thus the Fifth Circuit has not limited civil rights removal jurisdiction to prosecutions under broadly defined state statutes which easily afford the opportunity for abuse. That court has consistently held that it is the petitioner's allegations that control, and that, whatever the charge, if the petitioner alleges that he is actually being prosecuted for federally protected activity an evidentiary hearing is required; ${ }^{103}$ petitioner's proof of his allegations will result in the federal court retaining jurisdiction.

101393 F.2d 468, 475 (5th Cir. 1968). Judge Godbold basically agreed with this approach in his separate opinion:

The use of the label 'vagrancy' in the charges against them instead of the label 'trespass' does not require a result different than Rachel. The inquiry is to the scope and character of the conduct engaged in by the accused, not to categorizations, accurate or inaccurate, given to that conduct in the making of the criminal charges.

Id. at 476 (Godbold, J., concurring in part and dissenting in part).

In one case the Fourth Circuit indicated in dicta that it also would allow removal in such cases if the conduct charged was of a nonviolent nature. South Carolina v. Moore, 447 F.2d 1067, 1070 (4th Cir. 1971). In a more recent case, however, the court adopted the approach of the Second and Third Circuits, allowing removal only when, under the allegations of the defendant, there is a direct conflict between the state and federal statutes. Frinks v. North Carolina, 468 F.2d 639 (4th Cir. 1972) (2-1 decision). See note 86 supra.

102 See Perkins v. Mississippi, 455 F.2d 7, 31 (5th Cir. 1972) (Brown, C.J., dissenting):

The punitive consequences of such ["attempted punishment"] prosecutions are not alleviated simply because the defendant is maliciously charged with allegedly unrelated criminal misconduct rather than the acts protected by Federal law. The result in either case is the same: impermissible State interference with the exercise of rights Congress has immunized against intimidation.

103 Walker v. Georgia, 417 F.2d 1, 5 (5th Cir. 1969): 
This is not the end of the need for such an expansionary approach, however, because the unscrupulous prosecutor could attempt to punish the exercise of federal rights not only by altering the charge, but also by postponing arrest until the termination of protected activity. Limiting removal to cases where the petitioners allege that they were engaged in protected activity at the time of arrest allows, in Judge Brown's opinion, "effective vindication of Federal rights through the removal remedy to be effortlessly circumnavigated by the simple expedient of holding the spurious arrest in abeyance until after the right has been exercised and the innocent defendant has begun to engage in 'unprotected activity." "104 Accordingly, the Fifth Circuit has not limited removal to those situations where the arrest was coterminous with the protected activity. In Achtenberg all of the defendants but one were arrested for vagrancy while sitting-in in the public library. ${ }^{105}$ The last defendant had left the library before the police arrived. Later that day she was refused service at a restaurant. It was only after she left the restaurant that she was arrested, also on a charge of vagrancy. ${ }^{106}$ In allowing removal for all of the defendants, the Achtenberg majority drew no distinction based on the time of arrest. Judge Godbold, however, dissented with regard to that one defendant not arrested while within the library:

On the particular day her presence on and movement about the streets of Hattiesburg, and into and out of the library and the stores, was close in time and in place with her efforts to use the library and the restaurant facilities of the two stores. But closeness or even concurrence is not the test-scope and quality of conduct charged to be a violation of law, measured against the four corners of conduct the exercise of which is guaranteed by the 1964 Act, is the test. ...

It is what the movant was actually doing with respect to the exercise of his statutory federally protected right, as determined in a hearing for remand, that controls and not the characterization given to the conduct in question by a state prosecutor....

Accord, Walker v. Georgia, 405 F.2d 1191, 1192 (5th Cir. 1969); Whatley v. City of Vidalia, 399 F.2d 521, 526 (5th Cir. 1968). But see Perkins v. Mississippi, 455 F.2d 7 (5th Cir. 1972).

104 Perkins v. Mississippi, 455 F.2d 7, 31-32 (5th Cir. 1972) (Brown, C.J., dissenting).

Judge Brown went on to say:

Under such a standard it would not be at all difficult to imagine the spectacle of a Thomas Rachel or a Sandra Adickes, cowering inside the sheltered sanctity of the restaurant or public library in the exercise of Federally protected rights, yet afraid to step outside into the arms of police officers waiting around the corner with trumped-up charges of vagrancy, bigamy or second-degree murder. An interpretation of Peacock entailing such consequences carries its own refutation.

Id. at 32. The fact situation that Judge Brown describes might, however, be a proper one for federal injunctive relief. See generally Younger v. Harris, 401 U.S. 37 (1971); Dombrowski v. Pfister, 380 U.S. 479 (1965). 
... The relation of cause and effect between protected civil rights activities of the Peacock petitioners and their baseless arrest is not subject to rational doubt. But cause and effect was rejected as the yardstick. Criminal charges are not removable on the ground that they are baseless and made to punish and deter exercise of protected rights. Charges are removable if quantitatively and qualitatively they involve conduct coterminous with activity protected under the Civil Rights Act . . . 107

Requiring, as has the Fifth Circuit, a hearing whenever a state criminal defendant removes on the basis that he was arrested and is being prosecuted, not for the acts alleged in the criminal charge, but because of unrelated civil rights activity, might greatly expand the possibility of abuse of the civil rights removal statute, ${ }^{108}$ and add to the congestion in the federal courts, possibilities specifically avoided by the Peacock Court. ${ }^{109}$ Furthermore, it would expand the scope of the factual inquiry which the district court must make on the motion to remand. The court must determine whether two seemingly unrelated events are, in fact, cause and effect. Judge Friendly has stated that " $[\mathrm{w}]$ hile Rachel does entail in some instances a trial preliminary to the determination of federal jurisdiction, this is on what the Court evidently considered to be a rather narrow issue, whether the conduct charged is within the area withdrawn by the federal statute from the ambit of allowable state prosecution-not ... on the very question that is the subject of the state criminal charge."'110

Thus, under any interpretation of Rachel and Peacock other than one based on the nature of the state criminal statute and its potential omitted).

${ }^{107} \mathrm{Id}$. at $476-77$ (Godbold, J., concurring in part and dissenting in part)(footnote

108 See generally Comment, 6 U. SAN Francisco L. Rev. 117 (1971). But cf. Amsterdam, supra note 11, at 832 .

109 See City of Greenwood v. Peacock, 384 U.S. 808, 832-33 (1966). The policy considerations articulated in Peacock are discussed at text accompanying notes 121-31 infra.

110 New York v. Davis, 411 F.2d 750, 755 (2d Cir.), cert. denied, 396 U.S. 856 (1969). Judge Brown has responded that

the argument that the distinction between Rachel and Peacock lies in the scope of the evidentiary hearing necessary to determine whether Federal rights have been violated by State criminal prosecutions overlooks entirely the fact that in either case the ultimate issue is the same-the motivation for the proceedings. Arrests and prosecutions arising from the peaceful attempts to gain service in places of public accommodation (as in Rachel) do not automatically entitle a defendant to remove his case to a Federal court. The petitioner must still allege and prove that he was arrested and prosecuted only because he was a Negro. Resolving such issues requires a factual inquiry no less extensive than that needed to determine whether prosecutions for "unprotected" conduct are merely smokescreens for an officially sanctioned deprivation of federal rights.

Perkins v. Mississippi, 455 F.2d 7, 32 (5th Cir. 1972) (dissenting opinion); see id. at 32-33 n.58.

This argument is too quick to dismiss the greater difficulty, and more complex factual considerations, in proving motive by proving a cause and effect relationship between two apparently unrelated events, than in dealing with only one event. 
conflict with a federal statute, it is necessary to either provide a hearing for any defendant who alleges that he is being prosecuted solely because of some protected activity or to draw some essentially arbitrary line as to when a hearing should be required. Any line drawn would be arbitrary because people can be harassed by prosecutions on any charge and on charges brought at any time. ${ }^{111}$

\section{Rachel AND Peacock REconsmeRED}

The test espoused by the Second Circuit in New York v. Davis ${ }^{112}$ best explains the different results in Rachel and Peacock and is most consistent with the policies underlying those decisions. Judge Friendly drew the line "between prosecutions in which the conduct necessary to constitute the state offense is specifically protected by a federal equal rights statute under the circumstances alleged by the petitioner, and prosecutions where the only grounds for removal are that the charge is false and motivated by a desire to discourage the petitioner from exercising or to penalize him for having exercised a federal right."113 Application of this test reaches the result of the Supreme Court in Rachel and Peacock without relying on inferences from a single citation in a footnote ${ }^{114}$ or on a single sentence of the opinion, ${ }^{115}$ in a manner consistent with all of the language in Peacock. ${ }^{116}$

In Rachel the federal and state statutes both dealt with the same conduct-the presence of one person on the property of another. If the alleged motivation of the restaurant manager was present, then any application of the state's trespass statute would run afoul of the Civil Rights Act of 1966. Allowing removal under such circumstances extends Strauder only slightly, ${ }^{117}$ since, as applied to defendants asked to leave for racial reasons, the state statute is in direct conflict with the federal law. This type of inevitable conflict does not occur in Peacock. The federal right to help register voters does not undercut state public safety laws concerning blocked streets, reckless driving, or assault. Certainly the federal statute does not authorize murder, to choose an

111 See notes 101-07 supra \& accompanying text.

112411 F.2d 750 (2d Cir.), cert. denied, 396 U.S. 856 (1969) (discussed at notes 87-89 supra \& accompanying text).

113411 F.2d at 754.

114 See text accompanying notes 83-85 supra.

115 See text accompanying notes 90-93 supra.

116 See New York v. Davis, 411 F.2d 750, 753-54 (2d Cir.), cert. denied, 396 U.S. 856 (1969).

117 The Court was limiting its deviation from the established doctrine. Referring to the Strauder-Powers decisions, the Court stated:

[W]e decline to repudiate those decisions, and we decline to do so not out of a blind adherence to the principle of stare decisis, but because after independent consideration we have determined ... that those decisions were correct in their basic conclusion that the provisions of $\S 1443(1)$ do not operate to work a wholesale dislocation of the historic relationship between the state and the federal courts in the administration of the criminal law.

City of Greenwood v. Peacock, 384 U.S. 808, 831 (1966). 
extreme example, to be used by black persons in the implementation of voting or public accommodations rights. ${ }^{118}$ Admittedly, a black person who has exercised his federal rights can be harassed by means of a spurious murder charge. Even if an allegation of such harassment, analogous to the petitioners' allegation in Peacock, is true, the state criminal statute is not brought into conflict with the federal equal rights statute. Rather, if the allegation is true, state officers are using the statute in a manner prohibited by federal law. The Peacock Court made it clear that section 1443(1) was not the proper remedy for such conduct. ${ }^{119}$ Thus Rachel and Peacock are best explained by the fact that in the former the truth of the petitioners' allegations would bring the state criminal law into direct conflict with a federal statute providing for equal rights, but in the latter no such conflict would arise. ${ }^{120}$ This interpretation not only best squares the two cases but also is responsive to the policy considerations articulated in Peacock.

Two persistent policy considerations can be noted in the Supreme Court's 1966 removal decisions. The Court did not want to place a federal district judge in the position of being required to predict how a particular federal claim would be received in the state courts, ${ }^{121}$ and was reluctant to adopt an interpretation of section 1443(1) which would permit large numbers of criminal defendants to be able to force their way, even temporarily, into the federal courts. ${ }^{122}$

The first concern, based on considerations of federalism, ${ }^{123}$ is best assuaged by the establishment of a clear line between the removable and the nonremovable state prosecution. For example, although federal diversity jurisdiction is a product of the fear that state courts might be prejudiced against nonresidents, ${ }^{124}$ removal pursuant to that jurisdictional provision is automatic upon the allegation of diverse citizenship. ${ }^{125}$ That procedure is easily palatable to the states because the existence of such a specific rule means that the federal court need not

118 See South Carolina v. Moore, 447 F.2d 1067 (4th Cir. 1971).

119384 U.S. at 829-31.

120 A slight variation occurs when only one of the acts necessary for conviction under the state criminal statute is protected by federal law. In one case the defendants were prosecuted under the state's aggravated burglary statute, a charge which includes elements of both unauthorized entry and battery while on the premises. The defendant's removal petition alleged that he had entered a restaurant in an attempt to gain service. The Fifth Circuit held that remand without a hearing was improper because if the entry had been peaceful, then one of the acts required for conviction under the criminal statute was expressly authorized by the Civil Rights Act of 1964, making the very act of prosecution a violation of federally protected rights. The court suggested that if violence had occurred following a federally protected entry into the restaurant then the proper state charge would be simple burglary. Wyche v. Louisiana, 394 F.2d 527 (5th Cir. 1967).

121 See Georgia v. Rachel, 384 U.S. 780, 803-04 (1966) ; City of Greenwood v. Peacock, 384 U.S. 808, 828 (1966).

122 City of Greenwood v. Peacock, 384 U.S. 808, 832 (1966).

123 See Georgia v. Rachel, 384 U.S. 708, 803-04 (1966); cf. City of Greenwood v. Peacock, 384 U.S. 808, 833-34 (1966).

124 See Martin v. Hunter's Lessee, 14 U.S. (1 Wheat.) 304, 347 (1816); United States v. DeVeaux, 9 U.S. (5 Cranch) 61, 87 (1809).

126 See 28 U.S.C. $\$ \S 1446-47$ (1970). 
inquire whether the litigants could have their dispute decided impartially in a particular state court. The rule established by the Strauder-Powers decisions, requiring a facially unconstitutional state statute before a prosecution could be removed, provided similar clarity. ${ }^{126}$

The other concern of the Court, based upon considerations of federal judicial administration, is that an expansive interpretation of section 1443 would produce a flood of civil rights removal petitions requiring a substantial expenditure of time in the district courts devoted to hearings on petitioners' allegations, and at the appellate level in the review of remand orders. ${ }^{127}$ This problem might develop if section 1443 was interpreted to require a factual determination by the district court whenever the defendant alleges that he was arrested and charged with an offense in reprisal solely because of his prior participation in protected activity. Hearings on such allegations, necessarily involving an inquiry into the motives of the police in arresting the defendant, could place a huge burden on the federal courts. The Peacock Court may, however, have been overly concerned with this possibility. The Court's analysis of the number of removal petitions filed ignores the fact that the consolidation of large numbers of related petitions results in a far smaller number of distinct cases actually taking up the time of the federal courts. ${ }^{128}$ Furthermore, the Court ignored the fact that the choice is not one "between interlocutory federal litigation and no federal litigation,"129 for an increase in the number of removed cases should result in a significant, though not equivalent, ${ }^{130}$ decrease in the number of postconviction habeas corpus cases litigated in the federal courts. And this latter form of federal interference in the state judiciary is of a fundamentally more abrasive type because, rather than taking away a case from the state judge before he has heard it and reached a decision, it reverses him and requires that he retry the case or set the defendant free. ${ }^{131}$ Yet, exaggerated or not, the Supreme Court was clearly concerned with the overburdening effects of an expanded removal jurisdiction, and the lower federal courts must keep that concern in mind when interpreting Rachel and Peacock.

These policies do not, however, satisfactorily account for the different results in Rachel and Peacock. As the Fifth Circuit has pointed out, ${ }^{132}$ any type of criminal charge can be used to harass individuals for the exercise of federally protected rights, thus punishing them

126 See Amsterdam, supra note 11, at 858.

127 See City of Greenwood v. Peacock, 384 U.S. 808, 832-33 (1966); cf. id. at 834 (need for more judges).

128 See Whatley v. City of Vidalia, 399 F.2d 521, 522 n.1 (5th Cir. 1968).

129 Amsterdam, supra note 11, at 833.

130 The decrease in habeas corpus cases and direct appeals to the Supreme Court will not equal the number of cases removed because some trials held in the state courts result in verdicts of not guilty precluding the need for any federal intervention.

131 See Wilson, Federal Habeas Corpus and the State Court Criminal Defendant, 19 VAND. L. REv. 741, 741 (1966); Amsterdam, supra note 11, at 835.

132 See notes 101-06 supra \& accompanying text. 
unconstitutionally. If the Rachel defendants are to be given the opportunity to demonstrate that they are being prosecuted solely for protected activity, the Peacock defendants should be given the same opportunity. Regardless of the relationship between the state statute and the federal statute, prosecutors can effectively inhibit the exercise of federal rights by bringing baseless prosecutions. As has been indicated, the Court was overly concerned about congestion of the federal courts. And to the extent that congestion is a general problem in the federal courts, it is not clear why it is civil rights removal jurisdiction which should be sacrificed. To the extent delay is a problem, Congress can require removal petitions to be filed within a specific time after the onset of the prosecution, rather than allowing removal at any time before the state trial. Thus the Court or Congress should reconsider section 1443(1) and require an evidentiary hearing in any removed case in which the removal petition presents allegations sufficient to indicate that the prosecution is solely motivated by a desire to punish the defendant for his exercise of federally protected rights. The federal district courts should have broad discretion to remand in any case as soon as it becomes clear that the prosecution is not being used as a means of unconstitutional punishment.

Section 1443(1) can provide an important safeguard if so interpreted. As Professor Amsterdam has stated:

[W] here the federal contention is that the activity underlying the criminal charges is federally immune from state inhibition, the importance and the practicability of preserving a role for the state courts as federal law enforcers are considerably diminished, and the countervailing need for interlocutory federal intervention considerably increased. If this sort of federal immunity is to be made reasonably effective, the State must eventually relinquish or be deprived of the power to begin criminal proceedings which repress it. Arrest, charge, pretrial detention, or release on bond to compel appearance for hearing are effective methods of repression even where the charge is dismissed or dropped at the first court appearance. These repressive devices can be disarmed only if the state prosecutor and the chief of police can themselves be brought into the federal partnership, impressed with their responsibility for the protection or at least the recognition of federal guarantees. Ideally, the state justice of the peace or circuit judge might impress them with this responsibility. But among state judges he is the least likely and the least capable to do the job, however prodded by his appellate superiors. The direct power of the state appellate courts is limited in this regard, reaching the prosecutor only some considerable time after he has secured his conviction, and the police chief not at all. The likely willingness of the state appellate courts to assume the function is also limited: their judgments on particular federal issues 
and the general sensitivity to federal rights which grows out of the sum of particular judgments-and out of impressions concerning the factual contexts in which federal rights operate-are the creatures of cold records shaped by the state trial courts. For these reasons it is dubious wisdom to look to the state court system for efficient schooling of the prosecutor and police chief in their federal responsibilities; the necessary lesson can best be transmitted through the knowledge that both may be required to appear in a federal district court, at the outset of a prosecution, to justify the charges within federal constitutional requirements. Federal anticipatory jurisdiction demands of the State's attorney that he think in terms of federal law from the inception of proceedings, not merely when he is called upon to sustain an easy conviction on appeal; and it demands of the police chief that he appear and testify before a court whose very authority in the case demonstrates the immediacy of federal law. ${ }^{133}$

\section{AN OVERVIEW}

Under any of the suggested interpretations of Rachel and Peacock, section 1443(1) is not being used in a manner consistent with its title as a removal statute. That term conjures up the image of a case first brought in the state court, being transferred by the opposing party to the federal court with the trial to follow in that latter forum. This is what Congress envisioned in enacting a civil rights removal statute, ${ }^{134}$ and this is what occurs under sections 1441 and 1442, the other removal provisions of title 28. Such a scenario can occur in a limited number of cases removed under section 1443(1) pursuant to the Strauder-Powers decisions. When, as in Strauder, there is a state statute regulating trial procedure which on its face deprives a class of citizens of rights guaranteed by a federal statute providing for equal civil rights, the federal district court, after making such a finding, should retain jurisdiction and try the case. ${ }^{135}$ If, however, it is the substantive criminal provision under which the defendant is being prosecuted which on its face contravenes a federal equal rights statute, then under Strauder, the same district court finding which establishes the propriety of the removal will require the immediate granting of a defendant's motion to dismiss the prosecution. ${ }^{138}$

183 Amsterdam, supra note 11 , at $837-38$.

134 See Cong. Globe, 39th Cong., 1st Sess. 475, 1759 (1866) (remarks of Senator Trumbull).

135 Although this result seems clear, such a trial may never have been held. See text accompanying note 139 infra. In the only Supreme Court decision ordering removal on the basis of an unconstitutional procedural statute, the Court ordered a reversal of the conviction but did not indicate that a new trial should be held in the federal court. Strauder v. West Virginia, 100 U.S. 303, 312 (1880).

136 Amsterdam, supra note 11, at 852. For a discussion of the differences between procedural and substantive claims under $\$ 1443(1)$, see $i d .852-62$. 
And so it is with cases successfully removed pursuant to Rachel. No matter which of the tests for removal under Rachel is adopted, a factual determination that removal is proper can only be made when the mere pendency of the prosecution results in a deprivation of a right protected by a relevant federal statute. Here also, a defendant's motion to dismiss will automatically be granted following removal..$^{137}$ Thus under the Rachel extension of Strauder there are no circumstances under which a state criminal trial will take place in a federal forum. ${ }^{138}$ This result was clearly understood and expected by the Supreme Court, for it posed the question: "If the removal jurisdiction is to be expanded and federal courts are to try ... cases not originally cognizable in the federal courts, what law is to govern, who is to prosecute, under what law is a convicted defendant to be sentenced and to whose institution is he to be committed ... ? ?139

Thus, under Rachel and Peacock, "removal" is largely a misnomer for section 1443(1). A federal forum will not be provided because of prejudice in the state forum. Rather, the statute as interpreted provides a means by which the federal courts can limit the ability of state prosecutors to harass individuals for their exercise of certain types of federally protected rights. Thus section 1443(1) under Rachel and Peacock is more akin to injunctive relief than to removal. Both federal injunctions of pending state criminal trials and civil rights removal followed by dismissal provide anticipatory relief for certain state defendants. The standards for availability of the two remedies overlap but are not contiguous. ${ }^{140}$ The degree of overlap largely depends, of course,

137 In ordering a removal hearing, one court of appeals stated:

The judgment of remand is reversed and the case is remanded to the trial court with directions that the court conduct a hearing on the factual issue posed by the motion to remand, that is to say, whether the entry made by [the defendant] ... was in the exercise of his right to enjoy equal access to a place of public accommodations under Section 201 of the Civil Rights Act. If so, it will be the duty of the district court to proceed to a disposition of the state prosecution for aggravated burglary. Since a determination by the trial court on the removability question if in favor of removal, would eliminate one of the ingredients of the state offense, then, of course, there would be nothing left for the United States District Court to do but to dismiss the state charge.

Wyche v. Louisiana, 394 F.2d 927, 929 (5th Cir. 1967).

138 Under any of the tests the district court, in order to sustain removal, must find that the defendant is being prosecuted solely because of protected activity. Thus dismissal follows immediately.

139 City of Greenwood v. Peacock, 384 U.S. 808, 833-34 (1966) (quoting Baines v. City of Danville, 357 F.2d 756, 768-69 (4th Cir.), aff'd mem., 384 U.S. 890 (1966)). 140 The relative degree of irritation to the state judiciary resulting from these two means of federal pre-trial relief is unclear. The American Law Institute has concluded:

An injunction is a far more delicate remedy than removal, since an injunction will issue only after a judicial determination of irreparable harm, while removal automatically brings the state proceedings to a halt unless the case is remanded. It is of less importance that a properly restricted formula be devised if injunction, rather than removal, is contemplated, since the formula will be applied initially by a federal judge in the case of an injunction, and is not mechanically applicable as it would be with removal. There are certainly circumstances in which an injunction can issue without requiring the federal courts to prejudge their brethren of the state judiciary.

ALI Study of the Division of JuRIsdiction Between State and federad Courts 
on which interpretation of Rachel and Peacock is adopted. But regardless of that choice, section 1443(1) is clearly available only to defendants prosecuted for the exercise of rights provided by federal equal rights statutes. It does not provide any remedy for the defendant who is prosecuted for his free speech or other exercise of general rights. ${ }^{141}$

\section{CONCLUSTON}

Despite the history and terminology of section 1443(1), Rachel and Peacock make it clear that that statute is not truly a removal statute. Rather, section 1443(1) provides another means whereby the federal courts can intervene in state court proceedings and cause an immediate dismissal of the criminal prosecution. And, interpreted in a manner most consistent with Rachel and Peacock, civil rights removal is limited even in this scope to the situation where, under the facts alleged and proven by the defendant, the state criminal statute itself comes into direct conflict with a federal statute providing for equal civil rights. Thus, Congress' decision in 1964 to "allow the courts to deal case by case with situations as they arise,"142 rather than amending section 1443, results in a civil rights removal statute which is largely a phantom. The Supreme Court has interpreted the statute in a manner that expands Strauder only slightly, and in decisions that have led to great confusion in the lower federal courts. If removal is to have a real function, the Supreme Court must reconsider its decisions and allow defendants the opportunity to prove in federal court that, whatever the charge, they are being prosecuted solely because of their exercise of federal rights. In the alternative, if Congress truly desires to provide a federal forum for certain classes of criminal prosecutions or certain classes of defendants, it is incumbent on it to answer the questions posed by the Peacock Court ${ }^{143}$ and to define specifically the appropriate cases for removal.

\$ 1312 (c), comment at 206 (1969). Professor Currie has responded by asking: "isn't it doubtful that state judges would be more irritated by the everyday process of removal than by the extraordinary remedy of injunction?" D. CURRIE, FEDERAT CoURTS 609 (1968). This question fails to distinguish between the common forms of removal and the equally "extraordinary" civil rights removal.

141 See notes 43-46 supra \& accompanying text.

142110 CoNG. REC. 6956 (1964) (remarks of Senator Dodd).

143 Text accompanying note 139 supra. 